\title{
PENGARUH TOTAL ASSETS TURNOVER DAN INVENTORY \\ TURNOVER DALAM MEMPREDIKSI PERTUMBUHAN \\ LABA PADA PERUSAHAAN PERDAGANGAN YANG TERDAFTAR DI BURSA EFEK INDONESIA
}

\author{
Darwis Tamba \\ Yan Christin Br. Sembiring
}

\begin{abstract}
Abstrak
Tujuan penelitian ini adalah untuk menguji secara empiris total assets turnover (TAT) dan inventory turnover (IT) yang berpengaruh terhadap pertumbuhan laba pada perusahaan perdagangan yang terdaftar di Bursa Efek Indonesia secara simultan dan parsial. Populasi dalam penelitian ini diambil dari perusahaan perdagangan yang terdaftar di Bursa Efek Indonesia selama tahun 2014-2016 yaitu 58 perusahaan. Adapun metode yang digunakan adalah metode purposive sample dimana perusahaan yang masuk dalam kriteria adalah berjumlah 21 perusahaan. Hasil analisis menunjukkan bahwa data-data yang digunakan dalam penelitian ini telah memenuhi uji asumsi klasik, yang meliputi: tidak terjadi gejala multikolinearitas, tidak terdapat autokorelasi, tidak terjadi heteroskedastisitas, dan data terdistribusi normal. Dari hasil analisis regresi linier berganda menunjukkan bahwa variabel TAT dan IT tidak berpengaruh signifikan terhadap pertumbuhan laba secara simultan dan parsial.
\end{abstract}

Kata kunci : $\quad$ Total Asset Turnover (TAT), Inventory Turnover (IT), dan Pertumbuhan Laba

\section{PENDAHULUAN}

Masyarakat pada umumnya mengukur keberhasilan suatu perusahaan berdasarkan dari kinerjanya.Kinerja perusahaan dapat dinilai melalui laporan keuangan yang disajikan secara teratur setiap periode.Untuk dapat menginterpretasikan informasi akuntansi yang relevan dengan tujuan dan kepentingan pemakainya telah dikembangkan seperangkat teknik analisis yang didasarkan pada laporan keuangan yang dipublikasikan.Salah satu teknik tersebut yang diaplikasikan dalam praktek bisnis adalah analisis rasio keuangan.

Laba perusahaan diharapkan setiap periode akan mengalami kenaikan, sehingga dibutuhkan estimasi laba yang akan dicapai perusahaan untuk periode mendatang. Estimasi terhadap laba dapat dilakukan dengan menganalisis laporan keuangan.Analisis laporan keuangan yang dilakukan dapat berupa perhitungan dan interprestasi melalui rasio keuangan.

Total Assets Turnover berfungsi untukmengukur kemampuan perusahaan menggunakan total aktivanya dalammenghasilkan 


penjualan bersih (Ang, 1997). Semakin besar TAT
menunjukkansemakin efisien penggunaan seluruh aktiva
perusahaan untuk menunjang kegiatanpenjualan.Hal ini
menunjukkan bahwa kinerja perusahaan semakin baik
sehinggadapat meningkatkan laba perusahaan.

Inventory Turnover yaitu perbandingan antara harga pokok penjualandengan persediaan rata-rata.Inventory Turnover yang tinggi menandakan semakin tingginya persediaan berputar dan juga menandakan efektifitas manajemen persediaan. Dengan inventory turnoveryang tinggi berarti biaya yang tertanam di persediaan rendah sehingga biaya terkait dengan persediaan dapat dihindarkan sehingga perusahaan akan mampu meningkatkan labanya.

Taruh (2011) dalam penelitiannya menunjukkan bahwa rasio aktivitas yang diukur dengan Total Assets Turnover (selanjutnya disebut TAT) tidak berpengaruh signifikan dengan pertumbuhan laba. Hal ini sejalan dengan penelitian Astuti (2014). Akan tetapi, hal ini tidak sejalan dengan penelitian Tristi (2012) dan Cahyaningrum (2012). Masing-masing penelitian mereka menunjukkan bahwa TAT berpengaruh negatif signifikan terhadap pertumbuhan laba.Penelitian Gunawan dan Wahyuni (2013) menyatakan bahwa TAT berpengaruh positif signifikan terhadap pertumbuhan laba.TAT merupakan perbandingan antara penjualan bersih (net sales) terhadap total aset. TAT berfungsi untuk mengukur kemampuan perusahaan menggunakan total aktivanya dalam menghasilkan penjualan bersih.

Gunawan dan Wahyuni (2013) dalam penelitiannya menunjukkan bahwa rasio likuiditas yang diproksikan dengan Current Rasio (selanjutnya disebut CR), rasio leverage yang diproksikan dengan Debt to Equity Ratio (selanjutnya disebut DER) menunjukkan bahwa CR dan DER tidak berpengaruh signifikan terhadap pertumbuhan laba. Hal ini sejalan dengan penelitian yang dilakukan oleh Astuti (2014) dan Cahyaningrum (2012).Selain itu, Gunawan dan Wahyuni (2013) juga meneliti rasio aktivitas yang diproksikan dengan Inventory Turnover (selanjutnya disebut IT) yang menunjukkan bahwa IT berpengaruh positif signifikan terhadap pertumbuhan laba.Hal ini tidak sejalan dengan penelitian Astuti (2014) yang menyatakan bahwa IT tidak berpengaruh signifikan terhadap pertumbuhan laba.

Berdasarkan bukti empiris yang menghubungkan antara TAT dan IT terhadap pertumbuhan laba (pertumbuhan Earning After Tax) masih menunjukkan hasil yang berbeda-beda, maka penelitian ini menguji 
bagaimana pengaruh rasio-rasio keuangan tersebut terhadap pertumbuhan laba terutama pada sektor perdagangan di Bursa Efek Indonesia (BEI) periode 2014-2016 Pemilihan perusahaan perdagangan di BEI dikarenakan pendapatan terbesar dari sektor perdagangan merupakan penjualannya yangakan menghasilkan laba.

Berdasarkan uraian tersebut, maka peneliti tertarik untuk melakukan penelitian lebih lanjut dengan judul penelitian "Pengaruh Total Assets Turnover dan Inventory Turnover Dalam Memprediksi Pertumbuhan Laba Pada Perusahaan Perdagangan yang Terdaftar di Bursa Efek Indonesia"

\section{TELAAH TEORI}

\section{Telaah Teori}

\section{a. Pengertian dan Karakteristik Laba}

Pengertian laba menurut Ikatan Akuntan Indonesia (IAI, 2007) adalah kenaikan manfaat ekonomi selama satu periode akuntansi dalam bentuk pemasukan atau penambahan aktiva atau penurunan kewajiban yang mengakibatkan kenaikan ekuitas yang tidak berasal dari kontribusi peranan modal.Sementara pengertian laba yang dianut oleh struktur akuntansi sekarang ini adalah laba akuntansi yang merupakan selisih pengukuran pendapatan dan biaya.

Riahi dan Belkaoui (2006) menyebutkan bahwa laba memiliki beberapa karakteristik antara lain sebagai berikut:

a. Laba didasarkan pada transaksi yang benar-benar terjadi

b. Laba didasarkan pada postulat periodisasi, artinya merupakan prestasi perusahaan pada periode tertentu.

c. Laba didasarkan pada prinsip pendapatan yang memerlukan pemahaman khusus tentang definisi, pengukuran dan pengakuan pendapatan.

d. Laba memerlukan pengukuran tentang biaya dalam bentuk biaya historis yang dikeluarkan perusahaan untuk mendapatkan pendapatan tertentu.

Laba didasarkan pada prinsip penandingan (matching) antara pendapatan dan biaya yang relevan dan berkaitan dengan pendapatan tersebut.

\section{b. Pertumbuhan Laba}

Menurut Anoraga dan Pakarti dalam Cahyaningrum (2012) ada dua macam analisis untuk menentukan pertumbuhan laba yaitu analisis 
fundamental dan analisis teknikal.Analisis fundamental merupakan analisis historis atas kekuatan keuangan dari suatu perusahaan yang sering disebut dengan company analysis.Data yang digunakan adalah data historis, artinya data yang telah terjadi dan mencerminkan keadaan keuangan yang sebenarnya pada saat analisis. Dalam company analysis para analis akan menganalisis laporan keuangan perusahaan yang salah satunya dengan rasio keuangan.Analisis teknikal sering dipakai oleh investor, dan biasanya data atau catatan pasar yang digunakan berupa grafik. Analisis ini berupaya untuk memprediksi pertumbuhan laba di masa yang akan datang dengan mengamati perubahan laba di masa lalu. Teknik ini mengabaikan hal-hal yang berkaitan dengan posisi keuangan perusahaan.

Dalam hal ini analisis yang digunakan adalah analisis fundamental.Analisis fundamental merupakan analisis yang berkaitan dengan kinerja perusahaan.Kinerja perusahaan dapat diketahui melalui rasio keuangan.

\section{c. Laporan Keuangan}

Laporan keuangan digunakan untuk mengetahui perkembangan suatu perusahaan dan kondisi keuangan perusahaan. Pada dasarnya, laporan keuangan merupakan hasil dari proses pencatatan, penggolongan dan peringkasan dari kejadian-kejadian yang bersifat keuangan dengan cara setepat-tepatnya sebagai alat untuk berkomunikasi antara data keuangan atau aktivitas suatu perusahaan dengan pihak-pihak yang berkepentingan. Pihak-pihak yang berkepentingan terhadap laporan keuangan maupun perkembangan suatu perusahaan adalah pemilik perusahaan, manajer, kreditur, investor, pemerintah, dan karyawan (Munawir, 2004).

Secara umum kegunaaan informasi keuangan hasil akuntansi adalah sebagai dasar prediksi bagi pemakainya.Laporan keuangan yang disajikan harus relevan dengan kebutuhan dari masing-masing pemakai.Oleh karena itu, analisis laporan keuangan sangat dibutuhkan untuk memahami informasi laporan keuangan (Asyik dan Sulistyo, 2000).

Ang (1997) menyatakan bahwa analisis laporan keuangan suatu perusahaan tidak hanya dilakukan untuk satu periode tertentu saja, tetapi diperlukan analisis komparatif (perbandingan), sehingga dapat dilihat hubungan keuangan atau kecenderungan (trend) yang bersifat signifikan.

\section{d. Total Assets Turnover (TAT)}


TAT menurut Darsono dan Ashari (2005) merupakan kemampuan perusahaan dalam menggunakan aktiva yang dimiliki untuk menghasilkan penjualan digambarkan dalam rasio ini. Semakin tinggi TAT maka akan semakin tinggi tingkat efisiensi perusahaan dalam penggunaan aktivanya sehingga membatasi pembelian aktiva baru. TAT menurut Syamsuddin (2009), mengukur berapa kali total aktiva perusahaan menghasilkan penjualan. Ini juga dapat diartikan TAT mengukur perputaran semua aktiva yang dimiliki perusahaan dan mengukur berapa jumlah penjualan yang diperoleh dari tiap rupiah aktiva.

\section{e. Inventory Turnover (IT)}

Menurut Harahap (2008), perputaran persediaan adalah menunjukkan seberapa cepat perputaran persediaan dalam siklus produksi normal. Semakin cepat perputarannya, semakin baik karena dianggap kegiatan penjual berjalan cepat. Perputaran persediaan merupakan berapa kali persediaan akan berputar dan kembali lagi. Perputaran persediaan merupakan aktivitas perusahaan yang jelas diperlukan dan diperhitungkan, karena dapat mengetahui efisiensi biaya yang berguna untuk memperoleh laba yang besar.

\section{Kerangka Konsep}

Kerangka konsep dibentuk untuk menunjukkan pengaruh variabel independen yaitu TAT dan IT terhadap variabel dependen yaitu pertumbuhan laba seperti gambar berikut:

Gambar 2.1. Kerangka Konsep

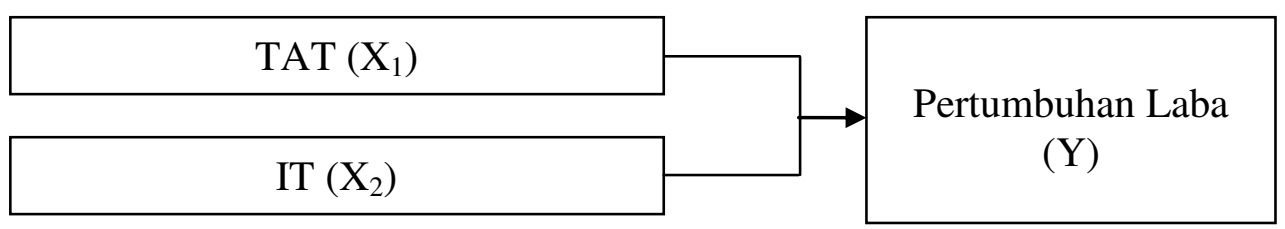

\section{Hipotesis}

Hipotesis merupakan jawaban sementara atas permasalahan dalam objek penelitian. Berdasarkan perumusan masalah, maka hipotesis penelitian ini adalah:

a. TAT berpengaruh terhadap ketepatan waktu pelaporan keuangan pada perusahaan perdagangan yang terdaftar di Bursa Efek Indonesia.

b. IT berpengaruh terhadap ketepatan waktu pelaporan keuangan pada perusahaan perdagangan yang terdaftar di Bursa Efek Indonesia. 
c. TAT dan IT berpengaruh terhadap ketepatan waktu pelaporan keuangan pada perusahaan perdagangan yang terdaftar di Bursa Efek Indonesia.

\section{METODE PENELITIAN}

\section{Populasi dan Sampel}

Populasi dalam penelitian ini adalah seluruh perusahaan perdagangan yang terdaftar di Bursa Efek Indonesia selama tahun 20142016.Teknik penentuan sampel dalam penelitian ini yaitu menggunakan metode purposive sampling. Purposive sampling (sampling bertujuan) adalah metode pengambilan sampel berdasarkan suatu kriteria tertentu, kriteria yang digunakan dapat berdasarkan perimbangan (judgement) atau berdasarkan kuota tertentu (Erlina, 2011). Pengambilan sampel dalam penelitian ini dilakukan secara purposive sampling dengan tujuan mendapatkan sample yang representatif sesuai dengan kriteria yang telah ditentukan.

Dalam penelitian ini, kriteria perusahaan perdagangan yang dijadikan sampel penelitian adalah:

a. Perusahaan perdagangan yang menyampaikan laporan keuangan pada tahun 2014-2016 yang telah diaudit.

b. Perusahaan perdagangan yang menggunakan mata uang rupiah.

c. Perusahaan perdagangan dengan nilai ekuitas positif pada tahun 20142016.

d. Perusahaan perdagangan yang tidak menghasilkan laba negatif pada tahun 2014-2016

Populasi dalam penelitian ini terdiri dari 58 perusahaan perdagangan. Populasi yang memenuhi kriteria untuk menjadi sampel berjumlah 21 perusahaan dengan 63 unit analisis ( $21 \times 3$ tahun).

\section{Operasionalisasi Variabel}

Operasionalisasi variabel merupakan batasan pokok pembahasan yang akan diteliti. Variabel yang diteliti dalam penelitian ini adalah:

TAT merupakan kemampuan dana yang tertanam dalam keseluruhan aktiva berputar dalam suatu periode tertentu atau kemampuan modal yang diinvestasikan untuk menghasilkan revenue. TAT memperlihatkan proporsi antara penjualan bersih dengan seluruh kekayaan yang dimiliki. TAT dapat dirumuskan sebagai berikut (Ang,1997):

$$
\text { Penjualan Bersih }
$$

$\mathrm{TAT}=$

Total Aset 
IT merupakan rasio yang digunakan untuk mengukur berapa kali dana yang ditanam dalam persediaan berputar dalam suatu periode. IT dapat dirumuskan sebagai berikut (Kasmir, 2012):

$$
\text { IT }=\frac{\text { Penjualan }}{\text { Persediaan }}
$$

Dalam penelitian ini variabel dependen adalah pertumbuhan laba dihitung dengan cara mengurangkan laba periode sekarang dengan laba periode sebelumnya kemudian dibagi dengan laba pada periode sebelumnya. Pertumbuhan laba dirumuskan sebagai berikut:

$$
\text { Pertumbuhan Laba }=\frac{Y_{t}-Y_{t-1}}{Y_{t-1}}
$$

\section{Teknik Analisis Data}

Penelitian ini menggunakan metodeanalisis regresi linear berganda yang bertujuan untuk mengukur kekuatan asosiasi (hubungan) linear antara dua variabel atau lebih.

Adapun model yang digunakan dari regresi linear berganda yaitu:

Dimana:

$$
\mathrm{Y}=\beta 0+\beta 1 \mathrm{X} 1+\beta 2 \mathrm{X} 2+\mathrm{e}
$$

$\mathrm{Y}=$ Pertumbuhan laba

$\beta 0=$ Konstanta

$\beta 1, \beta 2=$ Koefisien

$\mathrm{X} 1=$ Total Assets Turnover

$\mathrm{X} 2$ = Inventory Turnover

$\beta 0=$ Konstanta

$\mathrm{e}=$ variabel pengganggu

\section{HASIL PENELITIAN DAN PEMBAHASAN}

\section{Uji Asumsi Klasik}

Model regresi yang baik adalah distribusi data masing-masing variabelnya normal atau mendekati normal.Pengujian normalitas dapat dilakukan dengan grafik histogram dan uji Kolmogorov - Smirnov (KS).Jika histogram berbentuk seperti lonceng, tidak menyimpang maka data terdistribusi normal.Apabila signifikansi uji $\mathrm{K}-\mathrm{S}>0,05$ maka data terdistribusi normal.Hasil olah data dapat dilihat dari tabel berikut ini: 


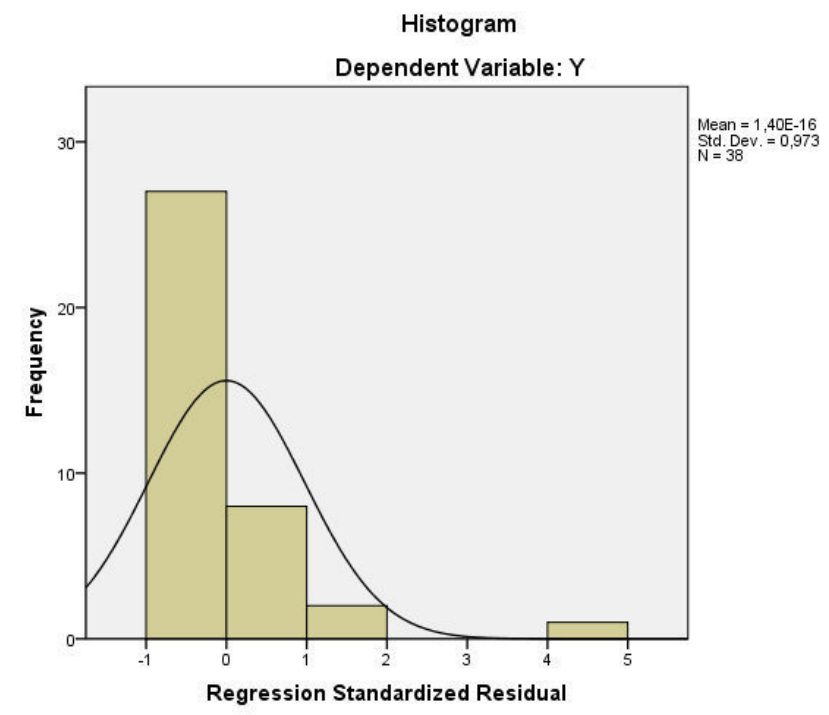

Gambar 4.1 Histogram Sebelum Transformasi

Dari histogram terlihat bahwa data tidak terdistribusi normal, yakni bentuk moderate positive skewness (Ghozali, 2016). Untuk mengatasinya, maka dilakukan transformasi data. Setelah dilakukan transformasi data maka didapatkan hasil berikut.

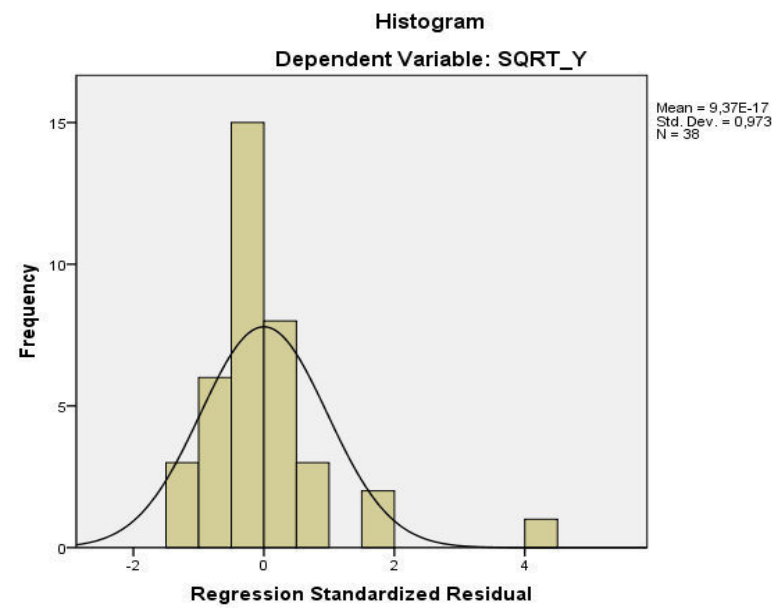

Gambar 4.2 Histogram Setelah Transformasi

Dalam penelitian ini juga dilakukan uji K-S setelah data ditransformasi, hasilnya dapat dilihat dari tabel berikut ini: 
Tabel 4.1 Hasil UjiKolmogorov-Smirnov Test

One-Sample Kolmogorov-Smirnov Test

\begin{tabular}{|ll|r|}
\hline & & $\begin{array}{r}\text { Unstandardiz } \\
\text { ed Residual }\end{array}$ \\
\hline Normal Parameters ${ }^{a}, \mathrm{~b}$ & Mean & 38 \\
& Std. Deviation &, 0000000 \\
Most Extreme Differences & Absolute &, 43619410 \\
& Positive &, 183 \\
& Negative &, 183 \\
Kolmogorov-Smirnov $Z$ & &,- 106 \\
Asymp. Sig. (2-tailed) & & 1,126 \\
\hline
\end{tabular}

a. Test distribution is Normal.

b. Calculated from data.

Sumber : Hasil Penelitian, 2018 (data diolah SPSS)

Dari tabel tersebut terlihat bahwa nilai signifikansi uji K-S adalah sebesar 0,158 >0,05 maka data terdistribusi normal.

Regresi yang baik adalah regresi dengan tidak adanya gejala korelasi yang kuat antara variabel bebasnya.Multikolinearitas adalah situasi adanya korelasi antara variabel-variabel independen antara yang satu dengan yang lainnya.Metode yang digunakan untuk mendeteksi multikolinearitas dalam penelitian ini adalah tolerance - Variance Inflector Factor (VIF). Multikolinearitas terjadi apabila nilai VIF $\geq 10$ dan nilai tolerance $\leq 0,10$ (Ghozali, 2016). Hasil olah data dapat dilihat dari tabel berikut ini:

Tabel 4.2 Hasil Uji Multikolinearitas

Coefficients $^{\mathrm{a}}$

\begin{tabular}{|c|c|c|c|c|c|c|c|c|}
\hline \multirow[t]{2}{*}{ Mod } & & \multicolumn{2}{|c|}{ Unstandardized Coefficients } & \multirow{2}{*}{$\begin{array}{c}\begin{array}{c}\text { Standardized } \\
\text { Coefficients }\end{array} \\
\text { Beta }\end{array}$} & \multirow[b]{2}{*}{ t } & \multirow[b]{2}{*}{ Sig. } & \multicolumn{2}{|c|}{ Collinearity Statistics } \\
\hline & & B & Std. Error & & & & Tolerance & VIF \\
\hline \multirow[t]{3}{*}{1} & (Constant) & ,780 &, 210 & & 3,710 & 001 & & \\
\hline & TAT &,- 119 &, 079 &,- 245 & $-1,496$ & , 144 & ,997 & 1,003 \\
\hline & IT &, 003 &, 013 &, 043 & 264 & ,793 & 997, & 1,003 \\
\hline
\end{tabular}

a. Dependent Variable: SQRT_Y

Sumber Hasil Penelitian, 2018 (data diolah SPSS) 
Dari Tabel 4.2 menunjukkan hasil perhitungan nilai tolerance tidak ada variabel independen yang memiliki nilai tolerance yang kurang dari 0,10 yang berarti tidak ada korelasi antarvariabel independen yang nilainya lebih dari 95\%. Hasil perhitungan nilai VIF juga menunjukkan hal yang sama tidak ada satu variabel independen yang memiliki nilai VIF lebih dari 10. Jadi dapat disimpulkan bahwa tidak ada multikolinearitas antarvariabel independen dalam model regresi.

Menurut Ghozali (2016) uji autokorelasi bertujuan menguji apakah dalam suatu model regresi linear ada korelasi antara kesalahan pengganggu pada periode $\mathrm{t}$ dengan kesalahan pada periode $\mathrm{t}_{-1}$ (sebelumnya).Jika terjadi korelasi, maka dinamakan ada masalahautokorelasi. Autokorelasi muncul karena observasi yang berurutan sepanjang waktu berkaitan satu sama lain. Masalah ini timbul karena residual (kesalahan pengganggu) tidak bebas dari satu observasi ke observasi lainnya. Hal ini sering ditemukan padadata runtut waktu atau time series karena "gangguan" pada individu atau kelompok cenderung mempengaruhi individu atau kelompok pada periode berikutnya. Model regresi yang baik adalah regresi yang bebas dari autokorelasi.

Pada penelitian ini, gejala autokorelasi dideteksi dengan menggunakan uji Durbin Watson atau DW-statistic.Kriteria pengambilan keputusan adalah jika du $\leq \mathrm{DW} \leq 4,00-\mathrm{du}$, berarti tidak terdapat gejala autokorelasi pada model tersebut. Hasil olah data dapat dilihat dari tabel berikut ini:

Tabel 4.3 Hasil Uji Autokorelasi

Model Summary

\begin{tabular}{|l|l|r|r|r|r|}
\hline Model & $\mathrm{R}$ & $\mathrm{R}$ Square & \multicolumn{1}{|c|}{$\begin{array}{c}\text { Adjusted R } \\
\text { Square }\end{array}$} & $\begin{array}{c}\text { Std. Error of } \\
\text { the Estimate }\end{array}$ & $\begin{array}{c}\text { Durbin- } \\
\text { Watson }\end{array}$ \\
\hline 1 &, $247^{\mathrm{a}}$ &, 061 &, 007 &, 44848 & 1,887 \\
\hline
\end{tabular}

a. Predictors: (Constant), IT, TAT

b. Dependent Variable: SQRT_Y

Sumber Hasil Penelitian, 2018 (data diolah SPSS)

Dari tabel 4.3diketahui nilai DW sebesar 1,887. Kriteria pengujian adalah du $\leq \mathrm{DW} \leq 4,00-$ du. Nilai du sebesar 1,662 , maka $1,662 \leq 1,887 \leq$ 2,338. Artinya tidak terjadi gejala autokorelasi pada model tersebut.

Uji asumsi klasik berikutnya adalah uji heteroskedastisitas yang bertujuan untuk menguji apakah dalam model regresi terjadi ketidaksamaan variance dari residual satu pengamatan ke pengamatan 
yang lain.Jika tidak ada pola tertentu serta titik-titik menyebar diatas dan dibawah angka nol pada sumbu Y, maka tidak terjadi heteroskedastisitas.Hasil uji heteroskedastisitas dapat terlihat pada gambar 4.3 berikut ini.

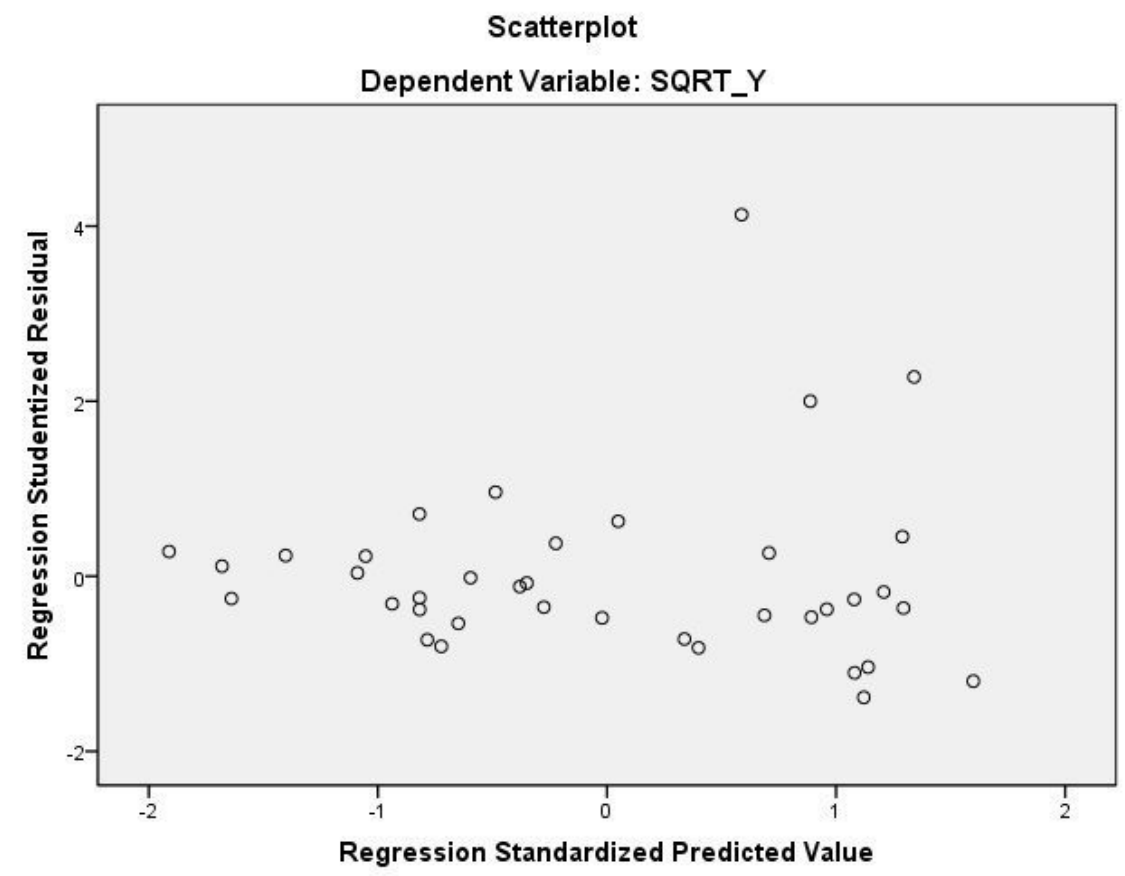

Gambar 4.3 Hasil Uji Heteroskedastisitas

Dari gambar 4.3 tersebut terlihat bahwa tidak ada pola tertentu serta titik-titik menyebar diatas dan dibawah angka nol pada sumbu Y, maka tidak terjadi heteroskedastisitas.

\section{Pengujian Hipotesis}

\section{a. Uji Statistik F}

Uji F digunakan untuk menguji signifikansi pengaruh TA dan IT terhadap pertumbuhan laba perusahaan perdagangan di Bursa Efek Indonesia secara simultan.Dengan menggunakan nilai probabilitas, jika probabilitas kurang dari 0,05, maka terdapat pengaruh yang signifikan antara variabel independen terhadap variabel dependen secara simultan. 
Tabel 5.1 Uji Statistik F

ANOVA $^{\text {b }}$

\begin{tabular}{|rl|r|r|r|r|r|}
\hline \multicolumn{1}{|l|}{ Model } & \multicolumn{1}{c|}{$\begin{array}{c}\text { Sum of } \\
\text { Squares }\end{array}$} & \multicolumn{1}{c|}{ df } & Mean Square & F & Sig. \\
\hline 1 & Regression &, 457 & 2 &, 229 & 1,136 &, $333^{\mathrm{a}}$ \\
& Residual & 7,040 & 35 &, 201 & & \\
& Total & 7,497 & 37 & & & \\
\hline
\end{tabular}

a. Predictors: (Constant), IT, TAT

b. Dependent Variable: SQRT_Y

Sumber Hasil Penelitian, 2018 (data diolah SPSS)

Dari Tabel 5.1dengan probabilitas signifikansi 0,333 yang nilainya lebih dari 0,05. Dengan demikian dapat disimpulkan bahwa tidak terdapat pengaruh yangsignifikan antara variabel independen terhadap variabel dependen (pertumbuhan laba) secara simultan.

\section{b. Uji Statistik t}

Hasil pengujian hipotesis ini bertujuan untuk mengetahui apakah TAT danIT berpengaruh secara individual terhadap pertumbuhan laba. Dengan menggunakan nilai probabilitas, jika probabilitas kurang dari 0,05, maka terdapat pengaruh yang signifikan antara variabel independen terhadap variabel dependen. Pengujian ini ditunjukkan dalam Tabel 4.5 berikut.

Tabel 5.2 Uji Statistik t

Coefficients $^{\mathrm{a}}$

\begin{tabular}{|ll|r|r|r|r|r|}
\hline \multicolumn{2}{|l|}{ Model } & \multicolumn{2}{|c|}{ Unstandardized Coefficients } & \multicolumn{2}{c|}{$\begin{array}{c}\text { Standardized } \\
\text { Coefficients }\end{array}$} & \\
\cline { 3 - 4 } & & \multicolumn{1}{|c|}{$\mathrm{B}$} & \multicolumn{1}{|c|}{ Std. Error } & \multicolumn{1}{|c|}{ Beta } & \multicolumn{1}{c|}{ Sig. } \\
\hline 1 & (Constant) &, 780 &, 210 & & 3,710 &, 001 \\
& TAT &,- 119 &, 079 &,- 245 & $-1,496$ &, 144 \\
& IT &, 003 &, 013 &, 043 &, 264 &, 793 \\
\hline
\end{tabular}

a. Dependent Variable: SQRT_Y

Sumber : Hasil Penelitian, 2018 (data diolah SPSS)

Berdasarkan hasil pengujian dengan regresi linier berganda yang ditunjukkan pada Tabel 5.2 tersebut, maka diperoleh persamaan regresi sebagai berikut.

$$
Y=0,780-0,119 \text { TAT }+0,003 \text { IT }
$$


Konstanta sebesar 0,780 menyatakan bahwa jika tidak memperhitungkan TAT dan IT, maka kemungkinan pertumbuhan laba adalah sebesar 0,780 .

Secara parsial, kedua variabel independen yang dimasukkan ke dalam model regresi tidak ada variabel yang berpengaruh signifikan terhadap pertumbuhan laba.

\section{PEMBAHASAN}

\section{a. Pengaruh TAT terhadap Pertumbuhan Laba}

Hasil pengujian pada Tabel 5.2menunjukkan bahwa variabel TAT tidak berpengaruh signifikan terhadap pertumbuhan laba. Hal ini dilihat dari nilai $t_{\text {hitung }}$ sebesar $-1,496$ yang dibandingkan dengan $t_{\text {tabel }}(\mathrm{df}=60$, $\alpha=0,05)$ adalah sebesar 2,000. Oleh karena penelitian ini diuji 2 arah maka titik kritis penerimaan Ho berada antara $-2,000$ sampai 2,000. Dengan demikian karena $t_{\text {hitung }}<t_{\text {tabel }}$ di mana $-1,496<2,000$ dan probabilitas yang diperoleh sebesar 0,144 yang lebih besar dari 0,05 $(\alpha)$ maka Ha ditolak. Angka koefisien regresi sebesar -0,119 mempunyai arti bahwa setiap penambahan 1 perputaran aktiva, maka pertumbuhan laba akan turun sebesar 0,119 dengan asumsi variabel lain dianggap konstan. Hasil penelitian ini tidak konsisten dengan penelitian Gunawan dan Wahyuni (2013), Hapsari (2007) yang menunjukkan bahwa TAT berpengaruh positif signifikan terhadap pertumbuhan laba. Hal ini mengindikasikan bahwa Semakin besar TAT menunjukkan perusahaan efisien dalam menggunakan seluruh aktiva perusahaan untuk menghasilkan penjualan bersihnya, sehingga laba yang didapat besar, sedangkan Tristi (2012) dan Cahyaningrum (2012) menyatakan bahwa TAT berpengaruh negatif signifikan terhadap pertumbuhan laba yang mengindikasikan TAT yang semakin rendahlah yang dapat mempengaruhi pertumbuhan laba. Akan tetapi, hasil penelitian ini mendukung hasil penelitian Astuti (2014) dan Taruh (2011) yang memperoleh hasil bahwa TAT tidak berpengaruh signifikan terhadap pertumbuhan laba.

\section{b. Pengaruh IT terhadap Pertumbuhan Laba}

Hasil pengujian pada Tabel 5.2 menunjukkan bahwa variabel IT tidak berpengaruh signifikan terhadap pertumbuhan laba. Hal ini dilihat dari nilai $t_{\text {hitung }}$ sebesar 0,264 yang dibandingkan dengan $t_{\text {tabel }}(d f=60$, $\alpha=0,05)$ adalah sebesar 2,000. Oleh karena penelitian ini diuji 2 arah maka titik kritis penerimaan Ho berada antara -2,000 sampai 2,000. Dengan demikian karena $t_{\text {hitung }}<t_{\text {tabel }}$ di mana $0,264<2,000$ dan probabilitas yang 
diperoleh sebesar 0,793 yang lebih besar dari 0,05 $(\alpha)$ maka Ha ditolak. Angka koefisien regresi sebesar 0,003 mempunyai arti bahwa setiap penambahan 1 perputaran persediaan, maka pertumbuhan laba akan naik sebesar 0,003. Hasil penelitian ini tidak konsisten dengan penelitian Gunawan dan Wahyuni (2013) yang menunjukkan bahwa IT berpengaruh positif signifikan terhadap pertumbuhan laba. Hal ini dikarenakan dengan ITyang tinggi berarti biaya yang tertanam di persediaan rendah sehingga biaya terkait dengan persediaan dapat dihindarkan sehingga perusahaan akan mampu meningkatkan labanya. Akan tetapi, hasil penelitian ini mendukung penelitian Astuti (2014) yang menyatakan bahwa IT tidak berpengaruh signifikan terhadap pertumbuhan laba.

\section{KESIMPULAN DAN SARAN}

\section{Kesimpulan}

Dari hasil penelitian analisis dan uji hipotesis yang telah dilakukan, peneliti mengambil kesimpulan baik secara simultan maupun parsial, TAT dan IT tidak berpengaruh signifikan terhadap pertumbuhan laba pada perusahaan perdagangan yang terdaftar di BEI pada tahun 2014-2016.

\section{Saran}

Dari kesimpulan yang telah diuraikan diatas, maka peneliti memiliki beberapa saran sebagai berikut:

a. Agar peneliti selanjutnya dapat menambah sampel perusahaan yang diteliti, jadi bukan hanya perdagangan saja.

b. Agar peneliti selanjutnya menambah periode pengamatan.

c. Agar peneliti selanjutnyameneliti varibel lainnya yang memungkinkan memiliki pengaruh.

\section{DAFTAR PUSTAKA}

Abdul, Halim. 2007. Manajemen Keuangan Bisnis. Ghalia Indonesia, Bogor.

Ang, Robert. 1997. Buku Pintar: Pasar Modal Indonesia, Penerbit Mediasoft Indonesia, Jakarta.

Astuti, Nara Indri. 2014. "Analisis Rasio Keuangan dalam Memprediksi Pertumbuhan Laba pada Perusahaan Telekomunikasi yang Terdaftar di BEI (2011-2013)", Naskah Publikasi, Universitas Muhammadiyah Surakarta. 
Asyik, Nur Fadjrih dan Soelistyo. 2000. "Kemampuan Rasio Keuangan dalam Memprediksi Laba", Jurnal Ekonomi dan Bisnis Indonesia, Vol.15, No. 3.

Cahyaningrum, Ndaru Hesti. 2012. “Analisis Manfaat Rasio Keuangan dalam Memprediksi Pertumbuhan Laba (Studi Kasus: Perusahaan Manufaktur yang Terdaftar di BEI Periode 2005-2010)". Universitas Diponegoro, Semarang.

Darsono dan Ashari. 2005. Pedoman Praktis Memahami Laporan Keuangan. Penerbit Andi, Jakarta.

Erlina. 2011. Metode Penelitian. P 87-88. Penerbit USU Press, Medan.

Finacial Accounting Standards Board (FASB). 1978. "Statement of Financial Accounting Concepts No.1: Objectives of Financial Reporting by Business Enterprises". Stamfort, Connecticut.

Ghozali, Imam. 2016. Aplikasi Analisis Multivariate dengan Program IBM SPSS 23. Edisi 8.Badan Penerbit UNDIP. Semarang.

Gujarati, Damodar. 1999. "Basic Econometrics", Mc Graw Hill Inc, New York.

Gunawan, Ade dan Sri Fitri Wahyuni. 2013. "Pengaruh Rasio Keuangan terhadap Pertumbuhan Laba pada Perusahaan Perdagangan di Indonesia", Jurnal Manajemen dan Bisnis, Vol.13, No. 01.

Hanafi, Mamduh M. dan Abdul Halim, 2005, Analisis Laporan Keuangan, Penerbit UPP AMP YKPN.

Hapsari, Epri Ayu. 2007. "Analisis Rasio Keuangan untuk Memprediksi Pertumbuhan Laba (Studi Kasus: Perusahaan Manufaktur yang Terdaftar di BEI Periode 2001-2005)”. Universitas Diponegoro, Semarang.

Harahap, Sofyan Safri. 2008. Teori Akuntansi. Edisi Revisi. Penerbit PT. Rajagrafindo Persada, Jakarta.

Hendra, S Raharjaputra.2009. Manajemen Keuangan dan Akuntansi. Penerbit Salemba Empat, Jakarta.

Ikatan Akuntan Indonesia (IAI). 2007. Standar Profesional Akuntan Publik. Salemba Empat, Jakarta.

Kasmir. 2012. Analisis Laporan Keuangan. Edisi Pertama. Penerbit PT. Rajagrafindo Persada, Jakarta.

Meythi. 2005. "Rasio Keuangan yang paling baik Untuk Memprediksi Pertumbuhan Laba: Suatu studi Empiris Pada Perusahaan Manufaktur Yang Terdaftar Di Bursa Efek Jakarta", Jurnal Ekonomi dan Bisnis, Vol. XI No. 2. 
Munawir, S. 2004. Analisa Laporan Keuangan. Edisi Keempat. Penerbit Liberty, Yogyakarta.

Murhadi, R Werner. 2013. Analisis Laporan Keuangan. Penerbit Salemba Empat, Jakarta.

Riahi, Ahmed dan Belkaoui. 2006. Teori Akuntansi. Edisi Kelima. Alih Bahasa: Yulianto, Ali Akbar, dan Risnawati Dermauli, Salemba Empat, Jilid 1, Jakarta.

Riyanto, Bambang. 1995. Dasar-dasar Pembelanjaan Perusahaan. Edisi 4, BPFE, Yogyakarta.

Syamsuddin, Lukman. 2009. Manajemen Keuangan Perusahaan. Edisi Baru. Penerbit PT. Rajagrafindo Persada, Jakarta.

Takarini, Nurjanti dan Erni Ekawati. 2003. "Analisis Rasio Keuangan dalam Memprediksi Perubahan Laba Pada Perusahaan Manufaktur di Pasar Modal Indonesia". Jurnal Ventura, Volume 6 Nomor 3.

Taruh, Victorson. 2011. "Analisis Rasio Keuangan dalam Memprediksi Perubahan Laba Pada Perusahaan Manufaktur di BEI".

Tristi, Anita. 2012. "Analisa Rasio Keuangan dalam Memprediksi Pertumbuhan Laba pada Perusahaan Food and Beverages yang Terdaftar di BEI". Universitas Pembangunan Nasional "Veteran", Jawa Timur. 